\title{
A tribute to Aino Marjatta Henssen (1925-2011)
}

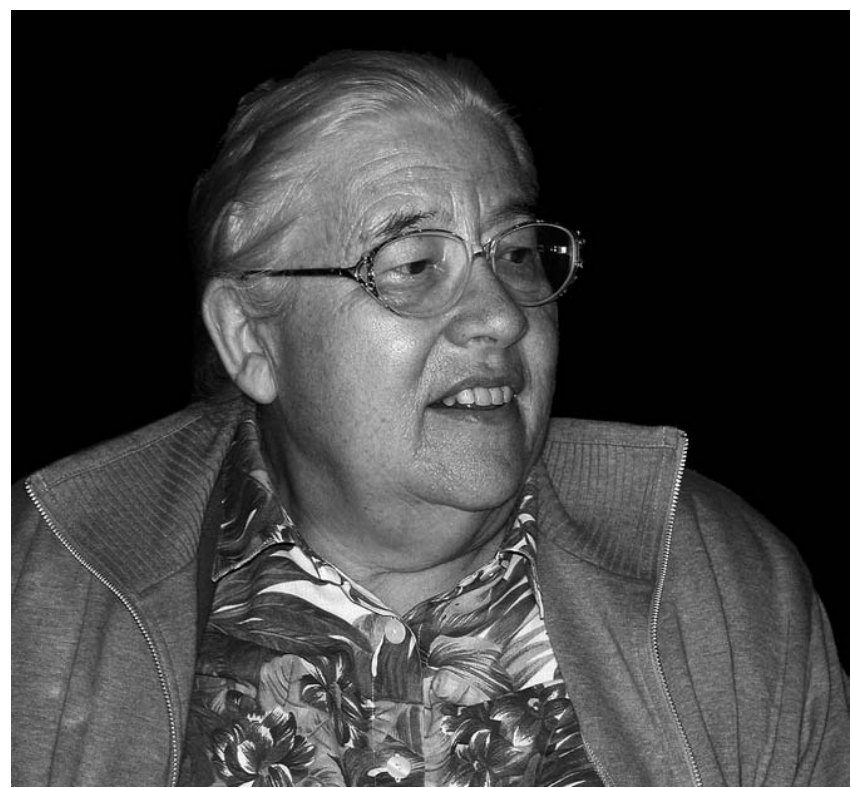

FIG. 1. Aino Henssen 2003 in Römerswil (Switzerland) (photo: R. Honegger)

On August 29, 2011 a unique person and prominent lichenologist passed away. Aino Henssen has been a leader in lichen systematics and taxonomy of cyanolichens for decades. Her textbook Lichenes - Eine Einführung in die Flechtenkunde (Henssen and Jahns 1974), co-authored by her former Ph. D. student Hans Martin Jahns, has been a standard text book for some decades and presented a classification system that integrated lichenized fungi with non-lichenized fungi. This classification has been influential for years and the detailed descriptions of accepted families and orders in this book have so far not been matched by any subsequent classification proposal.

Aino Henssen was born on April 12, 1925 in Elberfeld in the Ruhr area of Germany as the second of three children of the Finn Toini Saraste and the German folk tales studying scientist Gottfried Henssen. She grew up in the Ruhr area, Berlin, and after World War II, the family moved to Marburg. In this small university town the family moved into a large apartment that they shared for the first few years with other families. Aino would live in this apartment for most of her life and numerous visitors will remember her home in Biegenstrasse 52 filled with reminders of her travels, books and her impressive private lichen collection. She enjoyed inviting her students and co-workers and having colleagues visiting, who would often be offered home cooked dishes; cakes with wild berries and pickled mushrooms prepared according to Finnish recipes were among the items to be tasted.

Aino studied Biology in Freiburg for one semester and afterwards continued her studies in Marburg, where she graduated in 1953 with a doctoral thesis on the physiology of the aquatic flowering plant Spirodela polyrrhiza. 
After her Ph. D., she worked for a year in an agricultural institute at the University of Bonn before she took up a postdoctoral position at the Institute for Bacteriology in Berlin, where she worked until 1956 on actinomycetes, a field that continued to interest her throughout her career. She was especially interested in dung-inhabiting micro-organisms and later students in her mycology course regularly had to deal with piles of horse, cow and sheep dung to study her favourite groups of micro-organisms. In her career, Aino studied the taxonomy of actinomycetes intensely and described two new genera in 1957, Pseudonocardia Henssen and Thermomonospora Henssen, and a number of new species.

Next, Aino intended to work on mosses and liverworts, however, her work and travels in Fennoscandia introduced her to the diversity of lichens in these areas. She developed a love for lichens and they remained her passion until her death. As she had the opportunity to pursue her interest in lichenology not much was published by her on mosses and liverworts. Thanks to different scholarships she was able study in Finland, Sweden, Canada and the USA. Most important for her career were her first visits to the Botanical Institute in Helsinki in 1956 and then a research visit in Uppsala. Here she was influenced by the Swedish school of ascomycete systematics lead by John Axel Nannfeldt. Nannfeldt was very interested in the ontogeny of ascomata and classified major groups of ascomycetes based on their ontogenetic type (Nannfeldt 1932). Aino's study on the systematics of Lichinaceae (Henssen 1963) is a fine example of the first rate research produced by this group. At a time when lichenology was often local, Aino was one of the first truly international lichenologists. Scholarships allowed her to work from 1961-63 in Boulder (Colorado), Harvard (Massachussetts) and Toronto (Canada), to widen her horizons and to collect in North America. After these years during which Aino acquired a lot of international experience and new ideas for her research program, she was appointed curator of the Cryptogamic Herbarium at the Philipps-University in Marburg in 1963. She passed her habilitation in Systematic Botany in 1965, and in 1970 was appointed Associate Professor for thallophyte studies in Marburg, a position she held until her retirement in 1990. In Marburg she continued to work during her entire career both on lichens and actinomycetes, focusing on the taxonomy and systematics of these organisms. Her main interests in lichenology focused on the ascoma ontogeny of major lichen groups and the taxonomy of cyanophilic lichens. Seminal papers on comparative morphology and ontogeny of lichenized fungi include her study on the hemiangiocarpous development in lichens now classified in the subclass Ostropomycetidae (Henssen 1976), the review on gymnocarpous development types in the "Lecanoralean centrum" (Henssen et al. 1981), which roughly agrees with the Lecanoromycetidae in current classifications, and the studies on ascoma development in the Arthoniales (Henssen and Thor 1994). Her studies on cyanophilic lichens included various groups but focused mainly on the Lichinales with important contributions being her discussion of generic concepts in the Lichinaceae (Henssen 1979), description of the new family Gloeoheppiaceae (Henssen 1995), and taxonomy of the genus Heppia (Henssen 1994). However, she also had strong interest in other groups of cyanophilic lichens, such as the Arctomiaceae (Henssen 1969b), Coccocarpiaceae (Henssen and James 1982), Collemataceae (Henssen 1965), and the Pannariaceae (Henssen 1969a). She published more than 120 scientific articles, books and book chapters, over 100 of those on lichenized, lichenicolous or allied fungi. During her career, Aino described three orders (Arthoniales, Gyalectales, Lichinales), three families (Coccocarpiaceae, Coccotremataceae, Gloeoheppiaceae), 21 genera, over 150 species, and proposed more than 80 new combinations. Her systematic studies were important, since they consequently applied fungal characters for the delimitation of natural groups of lichen (fungi) with special focus on ascomatal characters and their development. At the time, these were new and revolutionary concepts when textbooks kept lichens as a separate group from fungi and when there was little, if any, interactions 
between taxonomists of lichen-forming and non-lichenized fungi. Therefore her studies and especially her textbook were important steps for the progress of lichenology in the 1970s and 1980s. Although she established treating lichenized fungi as such, she never overlooked the importance of photobionts (e.g. James \& Henssen 1976).

Aino Henssen's research was highly respected by her peers, which can be seen in the 11 or more lichenized fungi named after her, including Caloplaca hensseniana Kalb, Diploschistes hensseniae Lumbsch \& Elix, Gyalidea hensseniae Hafellner, Poelt \& Vězda, Lecanora hensseniae Vänskä, Nephroma hensseniae P. James \& F. J. White, Parmotrema hensseniae Krog, Rhizocarpon hensseniae Brodo, Rimularia hensseniae Hertel \& Rambold, Stephanocyclos henssenianus Hertel, Sticta ainoae D. Galloway \& J. Pickering, and Xanthoparmelia hensseniae O. Blanco, A. Crespo, Elix, D. Hawksw. \& Lumbsch. In addition, the genus Ainoa Lumbsch \& I. Schmitt was named in her honour. Aino was also among the first recipients of the Acharius Medal of the International Association for Lichenology that was first awarded at the IAL2 symposium in Sweden in 1992. Her 65th birthday was marked with a 'Festschrift' (Jahns 1990).

Aino devoted her life to lichens and had a great passion and enthusiasm for these organisms, in particular for the small Lichinaceae. This enthusiasm attracted students and made her a great teacher in the field. This passion, however, also made it difficult for her to give a full-hour lecture without being drawn into all the many interesting and exciting facts about lichens and sometimes losing sight of the main theme of the lecture. During her career as university professor she trained a number of students at $M$. Sc. level and supervised several $\mathrm{Ph}$. D. projects. She devoted much time to supervising her students, paying attention to details of their studies and taught them to question their ideas and to be self-critical. Students who worked with her on lichen and fungal Ph. D. projects include Hans Martin Jahns, Gerhard Keuck, Gernot Vobis, Bernd Renner, Burkhard Büdel, and Andreas Titze. Students who continued with scientific research after completing a $M$. Sc. thesis on a lichen topic with her include Thomas Friedl, and the authors of this obituary.

Another passion of Aino was field work and travelling. She often visited relatives in Finland (she spoke Finnish fluently) and Switzerland. She enjoyed debating her findings with colleagues, and participated in many international congresses. However, due to emerging health problems IAL2 was the last lichenological symposium she attended. She had an active field programme throughout her career and her collecting trips covered many areas in Europe and America, South Africa, New Zealand and Australia; the following countries are well represented in her collections, Germany, Austria, Switzerland, Finland, Sweden, Norway, France, United Kingdom, Ireland, Azores, Canary Islands, Canada, USA., Mexico, Bermuda, Costa Rica, Uruguay, Argentina, Chile, New Zealand, Australia, South Africa, the subantarctic Prince Edward Islands, Israel, Tajikistan and the Seychelles. Aino collected on her own, or with students and friends, on congress excursions and international expeditions, and during her holidays a hammer and chisel were never far away. She decided to give her personal collections to Helsinki, where c. 40000 specimens are currently being sorted and will be incorporated into the general lichen herbarium. Herbarium $\mathrm{MB}$ at the Philipps-University in Marburg has c. 17000 specimens, mostly duplicates of those in Helsinki, but also her type material and many lichen collections from other collectors that were deposited at MB. Together with the specimens her microscope slides, photo collection and field and note books are now housed in Helsinki.

It must have been difficult for Aino to pursue a scientific career as a woman in the 1950 s when science, as was the working world in general at that time, was mostly a male domain. She was always particularly grateful for a scholarship from the American Association of University Woman. Her enthusiasm, flexibility to accept different job possibilities, dedication to science, and to some extent her strength, helped her to obtain a position that allowed her not only to 
do but also to advance lichenology. For her it was natural to continue to follow her passion after her retirement and she continued to work on lichens at home where she not only had her private lichen herbarium and her library, but also microscopes and a freezing microtome. Her last paper was published in 2007 (Henssen 2007). Aino's last years had been overshadowed by illness, and she lived in a nursing home where she passed away peacefully at the age of 86 , refusing lifeprolonging intensive care treatment. Aino Henssen is buried in the main cemetery in Marburg under a birch tree, which she had planted herself about 40 years ago on her mother's grave in memory of her Finnish native country.

We wish to thank Teuvo Ahti (Helsinki), Rosmarie Honegger (Zürich), and Gernot Vobis (Bariloche) for sharing their memories of Aino with us while writing this obituary.

\section{REFERENCES}

Henssen, A. (1963) Eine Revision der Flechtenfamilien Lichinaceae und Ephebaceae. Symbolae Botanicae Upsalienses 18(1):1-123.

Henssen, A. (1965) A review of the genera of the Collemataceae with simple spores (excluding Physma). Lichenologist 3: 29-41.

Henssen, A. (1969a) Die Entstehung des Thallusrandes bei den Pannariaceen (Lichenes) mit einer generellen Diskussion über die Entwicklung lecanoriner und biatoriner Flechtenapothecien. Berichte der Deutschen Botanischen Gesellchaft 82: 235-248.

Henssen, A. (1969b) Eine Studie über die Gattung Arctomia. Svensk botanisk Tidskrift 63: 126-138.

Henssen, A. (1976) Studies in the developmental morphology of lichenized Ascomycetes. In Lichenology: Progress and Problems (D. H. Brown D. L. Hawksworth \& R. H. Bailey, eds): 107-138. Academic Press, London.
Henssen, A. (1979) Problematik der Gattungsbegrenzung bei den Lichinaceen. Berichte der Deutschen Botanischen Gesellschaft 92: 483-506.

Henssen, A. (1994) Contribution to the morphology and species delimitation in Heppia sensu stricto (lichenized Ascomycotina). Acta Botanica Fennica 150: $57-73$.

Henssen, A. (1995) The new lichen family Gloeoheppiaceae and its genera Gloeoheppia, Pseudopeltula and Gudelia (Lichinales). Lichenologist 27: 261-290.

Henssen, A. (2007) Leciophysma subantarcticum, a new cyanophilic lichen from the Southern Hemisphere. Bibliotheca Lichenologica 96: 129-135.

Henssen, A. \& Jahns, H. M. (1974) Lichenes. Eine Einführung in die Flechtenkunde. Stuttgart: Georg Thieme Verlag.

Henssen, A. \& James, P. W. (1982) The lichen genus Steinera. Bulletin of the British Museum (Natural History), Botany series 10: 227-256.

Henssen, A., Keuck, G., Renner, B. \& Vobis, G. (1981) The lecanoralean centrum. In Ascomycete Systematics. The Luttrellian Concept (D. R. Reynolds, ed.): 138-234. New York, Heidelberg, Berlin: SpringerVerlag.

Henssen, A. \& Thor, G. (1994) Developmental morphology of the "Zwischengruppe" between Ascohymeniales and Ascoloculares. In Ascomycete Systematics. Problems and Perspectives in the Nineties (D. L. Hawksworth, ed.): 43-56. NATO Advanced Science Institutes Series. New York: Plenum Press.

Jahns, H.M. (1990) Contributions to Lichenology in Honour of A. Henssen. Bibliotheca Lichenologica. 38: $1-427$.

James, P. W. \& Henssen, A. (1976) The morphological and taxonomic significance of cephalodia. In $\mathrm{Li}$ chenology: Progress and Problems (D. H. Brown D. L. Hawksworth \& R. H. Bailey, eds): 27-77. London: Academic Press.

Nannfeldt, J.A. (1932) Studien über die Morphologie und Systematik der nicht-lichenisierten inoperculaten Discomyceten. Nova Acta Regiae Societatis Scientiarum Upsaliensis 8: 1-368.

\section{H. Thorsten Lumbsch and Heidi Döring}

